\title{
Surgical Treatment in Acute Phase of Severe Burns - a Comprehensive Approach
}

Mihaela-Cristina Andrei', Andreea Grosu-Bularda', Oana Vermesan', Adrian Frunza', Serban Arghir Popescu', Sabina Ionita', Razvan Teodoreanu', Khalid Al-Falah', Tiberiu-Paul Neagu', Ioan Lascar ${ }^{1}$

\begin{abstract}
Major burn is considered the most severe type of injury, with high mortality risk and poor quality of life prognosis for survivors. Appropriate burn wound management may require multiple treatment modalities, with specific sequencing particular to each patient, addressing every injured area depending on burn surface and depth, patient's general status and also available infrastructure and burn center resources. Early excision of burn eschar and grafting with autologous split-thickness skin grafts remains the universal standard of surgical burn care in acute phase. Ongoing research is conducted for developing new skin substitutes that meet the ethical, safety efficiency and economical criteria in order to obtain adequate wound coverage when autologous skin grafts are not available. Each severe burned patient represents a complex case, requiring long-term multiple-stage and interdisciplinary treatment, adequate rehabilitation and follow-up program to obtain optimal functional results and socio-professional reinsertion.
\end{abstract}

Keywords: severe burns, acute phase, surgical treatment, skin grafts, skin substitutes

\section{Rezumat}

Arsurile majore reprezintä cel mai grav tip de traumatism, cu risc mare de deces și prognostic rezervat în ceea ce privește calitatea vieții supraviețuitorilor. Abordarea terapeuticä a leziunilor postcombustionale implicä un tratament multimodal, specific fiecărui pacient, în funcție de suprafața și profunzimea leziunilor, starea generală a pacientului cât și infrastructura și resursele existente în cadrul unității de îngrijire a pacientului ars. Excizia grefară precoce cu autogrefe de piele liberă despicată reprezintă standardul universal de tratament chirurgical în faza acută a arsurii. În prezent, continuă cercetările pentru dezvoltarea unor noi substituenți de piele pentru acoperirea suprafețelor arse excizate, când autogrefele nu sunt disponibile sau starea pacientului nu permite utilizarea acestora. Substituenții tegumentari trebuie să întrunească criterii etice, de siguranță, eficiență cât și economice pentru a putea fi utilizați pe scară largă pentru acoperirea defectelor postcombustionale. Fiecare pacient ars reprezintă un caz complex ce necesită tratament îndelungat, multistadial, impunând cooperare interdisciplinară. Urmărirea atentă a pacientului, reevaluarea periodică, efectuarea corecțiilor chirurgicale stadiale și încadrarea sa într-un program susținut de recuperare medicală sunt elemente esențiale pentru obținerea unor rezultate optime funcționale și estetice pentru o cât mai bună reinserție socio-profesională.

Cuvinte cheie: arsuri majore, faza acută, tratament chirurgical, grefe de piele, substituenți tegumentari 


\section{INTRODUCTION}

Major burn represents the most severe type of trauma, requiring high standard of treatment into regional specialized bun care centers ${ }^{1}$. According to American Burn Association (ABA), a major burn, which requires hospitalization in burn units, is represented by at least one of the following situations ${ }^{2,3}$ :

- Partial thickness burn more than $10 \%$ body surface, in patients under 10 or over 50 years of age;

- Partial thickness burn more than $20 \%$ body surface in adults;

- Full thickness burn more than 5\% body surface in any age group;

- Burns of any thickness on face, hands, feet, perineum, genitalia and major joints;

- Electrical or chemical burns;

- Inhalation injury;

- Associated trauma, pre-existing medical diseases, other acute illnesses, pregnancy, immunosuppression of any cause, other deficiencies;

- Suspicion of non-accidental burn (abuse, neglect) in children and people with disabilities;

- Associated psychosocial risk (suicidal attempt, a child in difficulty, psychiatric pathology, lack of family co-operation in the therapeutic process).

The pathophysiological evolution of severe burns has three stages ${ }^{4-8}$ :

1. The initial phase of acute trauma corresponds to the first 48-72 hours, when the post-combustional shock is installed. During this time, there is an important risk of hydro-electrolyte, metabolic imbalances and systemic complications, which may become fatal. During the initial period it is very important the quality and accuracy of general treatment (especially resuscitation performed within the first 24 hours) and local treatment, because the vital prognosis of the patient depends on it. The most frequent formula used is Parkland formula using $4 \mathrm{ml}$ crystalloid solutions $\mathrm{x} \mathrm{kg}$ x burn surface for the first 24 hours, from which half in the first 8 hours and the other half in the next 16 hours. This formula should be taken as a guideline and adapted as needed to the hemodynamic parameters.

2. The acute phase, after the first 72 hours, until spontaneous epithelization of superficial lesions and definitive skin coverage of profound lesions, which are early excised and grafted, this has been a standard care for decades; surgical treatment, prevention and control of systemic complications, prevention and control of infections, nutritional, metabolic and immunological support, monitoring the patient are essential therapeutic elements. The extensive moderate and major burn patient is an emergency patient, until definitive skin coverage and biological settle.

\section{The rehabilitation phase.}

\section{SURGICAL TREATMENT}

\section{Importance of early excision and grafting}

Since 1970s, based on the studies performed by slovenian plastic surgeon Zora Janzekovic, early surgical excision and grafting of deep burn wounds is considered mandatory, reducing blood loss, infectious risk, duration of hospitalization and mortality ${ }^{9-12}$.

Surgical protocols regarding burn wound management were refined over the years having in mind this essential principle of early excision and grafting.

We present a schematic surgical approach in the initial and acute phases of the burn treatment that ensures good long-term results in terms of survival and functional recovery (Figure 1):

Figure 1.

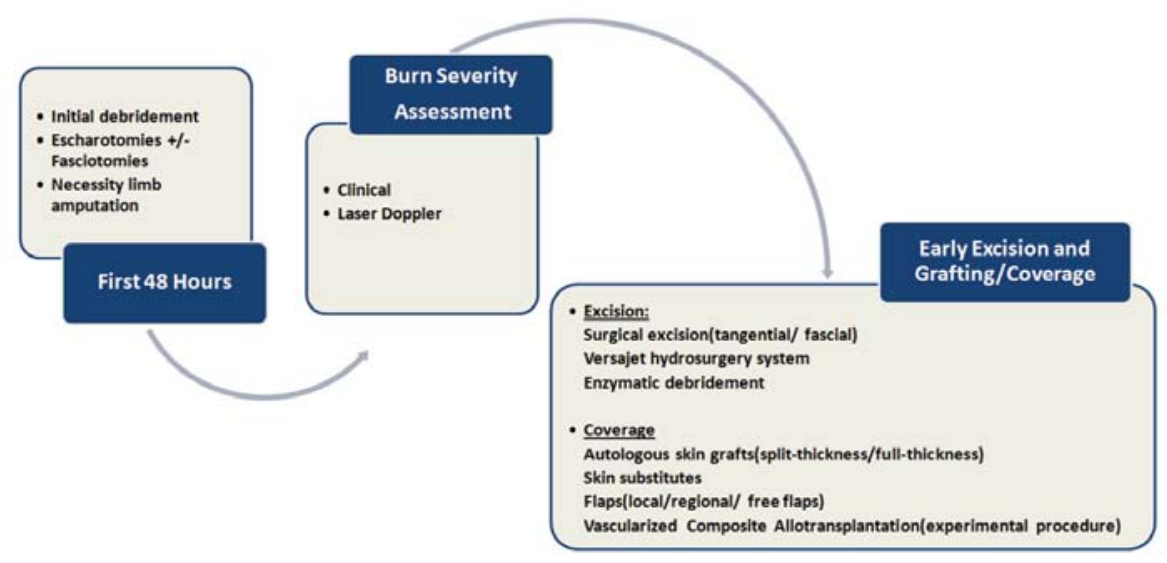




\begin{tabular}{|c|c|c|c|c|}
\hline Burn wound depth & Burn wound grade & Clinical evaluation & Layers of skin involved & $\begin{array}{l}\text { Days until complete } \\
\text { healing }\end{array}$ \\
\hline Superficial & I & Erythematous, painful & Epidermis & $3-4$ days \\
\hline Partial thickness & $\| A$ & Serous blisters, painful & $\begin{array}{l}\text { Epidermis and reticular layer of } \\
\text { dermis }\end{array}$ & 2-3 weeks \\
\hline Deep partial thickness & II B & $\begin{array}{l}\text { White eschar, hemorrhagic } \\
\text { blisters, pink and white spots, } \\
\text { less painful }\end{array}$ & $\begin{array}{l}\text { Deeper than the reticular layer } \\
\text { of dermis, but not the entire } \\
\text { dermis }\end{array}$ & 3-8 weeks \\
\hline Full thickness & III & $\begin{array}{l}\text { Black or white dry eschar, } \\
\text { painless }\end{array}$ & $\begin{array}{l}\text { Entire dermis and subcutaneo- } \\
\text { us tissue }\end{array}$ & Needs surgical treatment \\
\hline
\end{tabular}

\section{Clinical evaluation and management of burn wounds in the first $\mathbf{4 8}$ hours}

After the burned patient is admitted in the burn unit, the wounds are cleaned with soap and sterile water, debris are removed and an initial extent and depth of the burn is established (Table 1).

Regarding local tissue response to burn aggression, Jackson described in 1947 three zones of a burn wound ${ }^{14}$ :

- Zone of Coagulation: Area that suffers the most damage, with thrombosed blood vessels

- Zone of Stasis: Area surrounding zone of coagulation characterized by vasoconstriction; at first viable, but it may convert to non-viable tissue (coagulation area).

- Zone of Hyperemia: Peripheral area around the burn wound characterized by increased blood flow.

We can visualize below this specific zones in one of our patients together with a schematic representation of possibility of burn lesion evolution (Figure 2).

Figure 3 illustrates a patient suffering extensive second and third degree burns, evaluated carefully in the operating room after the initial cleaning of wounds at time of his admission.

The patient is transported to the operating room where, under general anesthesia/sedation, the surgical team performs:

- Burn wound cleaning using non-irritating antiseptic solutions (chlorhexidine in physiological saline solution, povidone-iodine, saline solution).

- Debridement of the broken and large blisters, the small ones can be left in place and emptied with small sterile needles.

- In the case of circumferential lesions, constrictive in the limbs, cervical, thoracic and abdominal region or if the tissue edema that develops during the acute phase of burn resuscitation, in the first 48 hours after injury, it is necessary to practice decompression incisions (escharotomies) as follows: the limb is incised at the medial-lateral lines, starting from the proximal to the distal at the level of the burned areas; thoracic wall incised at the level of the anterior axillary line starting from the clavicle to the marginal edge; abdominal wall - a transverse incision is requi-
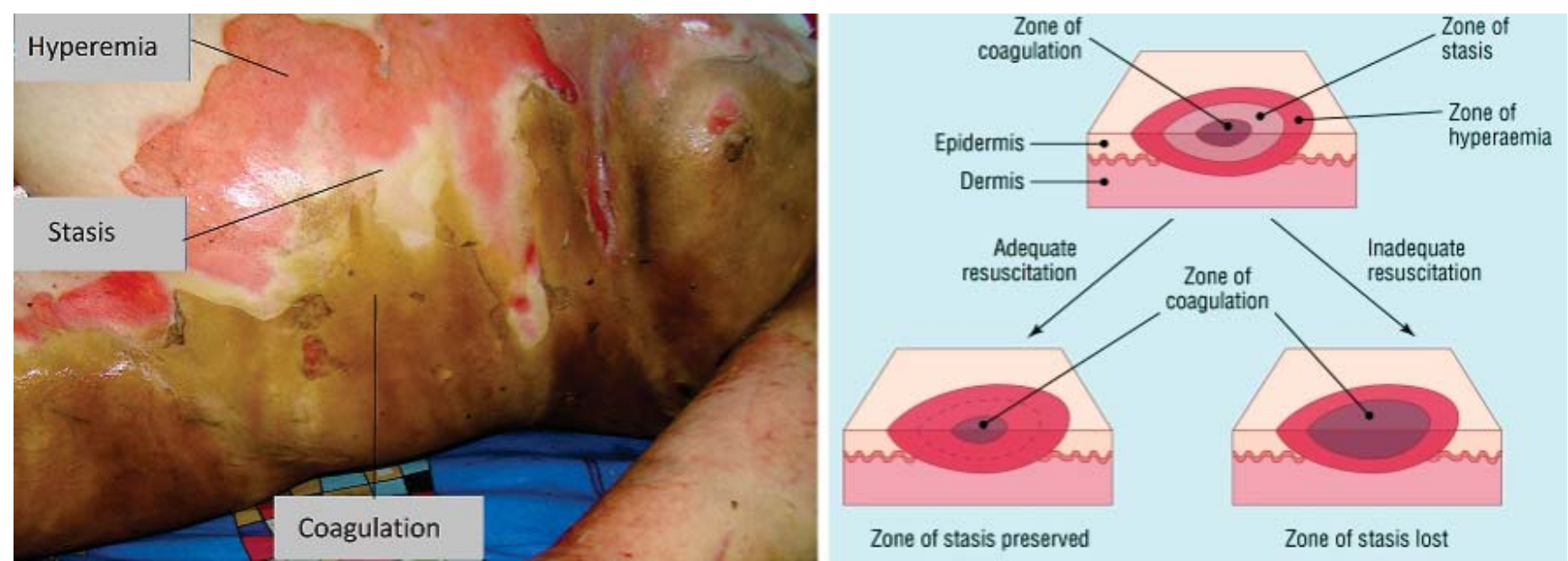

Figure 2. Modified after ${ }^{14}$ under Copyright $\left({ }^{\circ}\right.$ 2004, BMJ Publishing Group Ltd. 


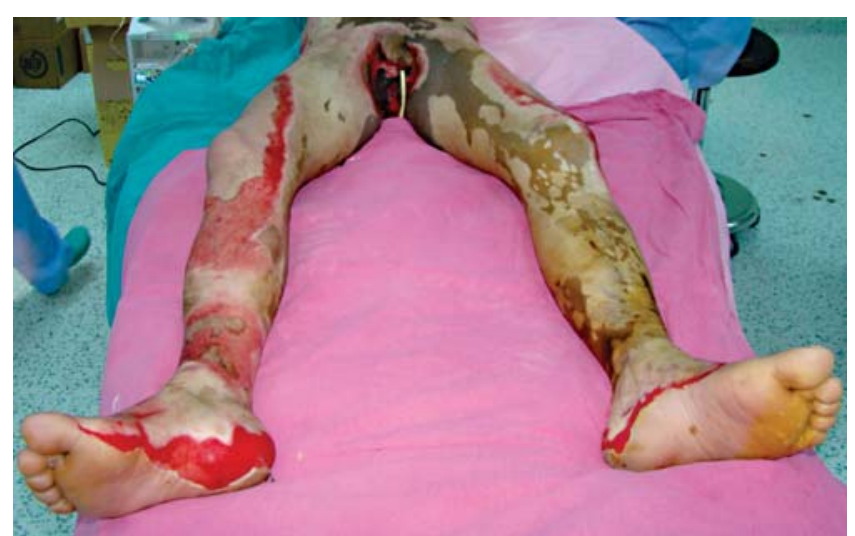

Figure 3.

red to connect the escharotomies from the anterior axillary line. Circumferential deep burns in the abdomen affects blood supply to the bowels, kidneys and other internal organs that results in hepatic and renal failure, intestinal ischemia, and restriction of diaphragmatic moves; if constricting the chest worsens pulmonary compliance associated with inhalation injury).

The escharotomies release the constricting tissue allowing the body tissues and organs to maintain their normal perfusion and function. Escharotomies release the constriction caused by burn eschar but do not remove the eschar. The burn eschar is removed by excision when the patient is stabile enough, after fluid resuscitation, to support a more extensive surgical intervention ${ }^{15,16}$.

- If the escharotomy does not restore the blood flow to the limb or we are in the situation of a compartment syndrome, fasciotomy is required. Fasciotomies are usually required in high-voltage electrocution burns and limb trauma ${ }^{16}$.

A compartment syndrome of the limbs causes permanent functional impairment or even the need for

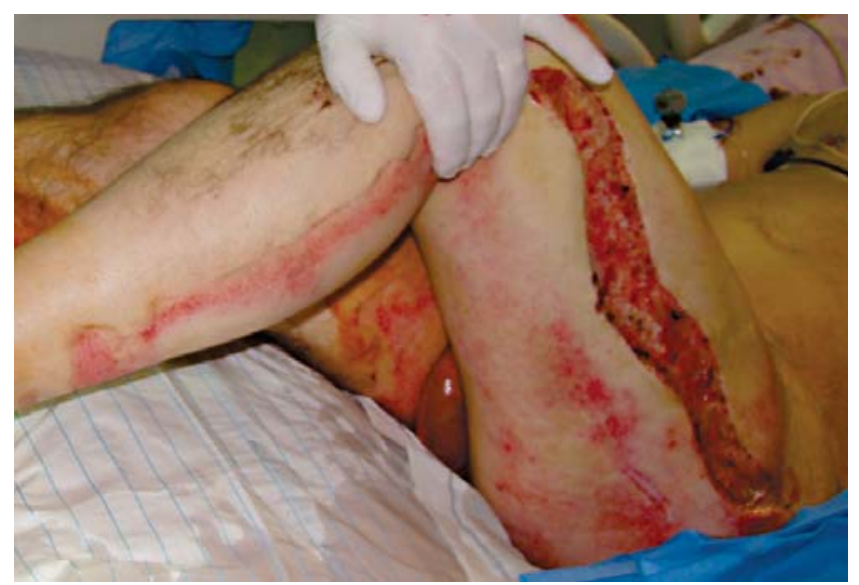

Figure 4. Escharotomy in the thigh.

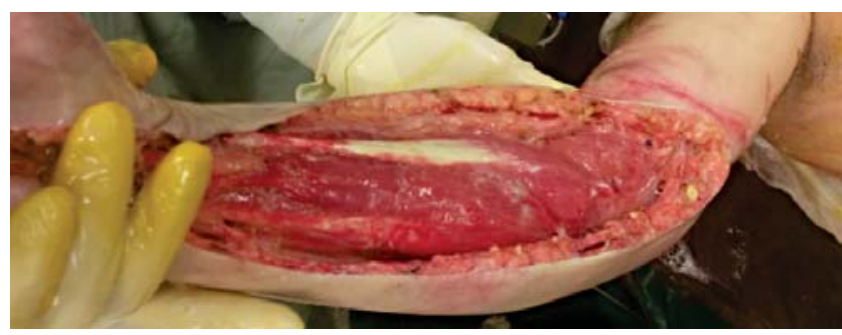

Figure 5. Fasciotomy of the right forearm and carpal tunnel decompression.

amputation. The need of limb amputation is demanded in two cases: compartment syndrome with ischemia and a carbonized limb (as we can see in Figure 6) ${ }^{17}$.

- After abundant lavage with warm sterile antiseptic and saline solution and adequate hemostasis, a sterile, rich, absorbent, non-constricting dressing is performed and the patient is transferred to an individual hospital intensive care room.

In the acute phase, correct positioning of the burn patient is very important in order to protect the wounds, reduce edema and the contraction forces in the wound, preventing scar contractions. The posturing includes: neck in moderate extension, without rotation, the abduction of the shoulders at 90 degrees, the trunk is straight without rotation, elbow in extension and supination, hand in slight extension of the radiocarpal joint, easy flexing of the MP joint, extension of PIP joint and DIP joint, abduction of the thumb, hip joint extension, abduction of 20 degrees, without rotation, full extension knee, neutral feet position (without plantar flexion $)^{18}$.

\section{Burn severity assessment}

After adequate fluid resuscitation and support of vital functions, the reevaluation of burn wound depth is required for decision regarding further surgical treatment, adapted to the severity of the injury and patient general status.

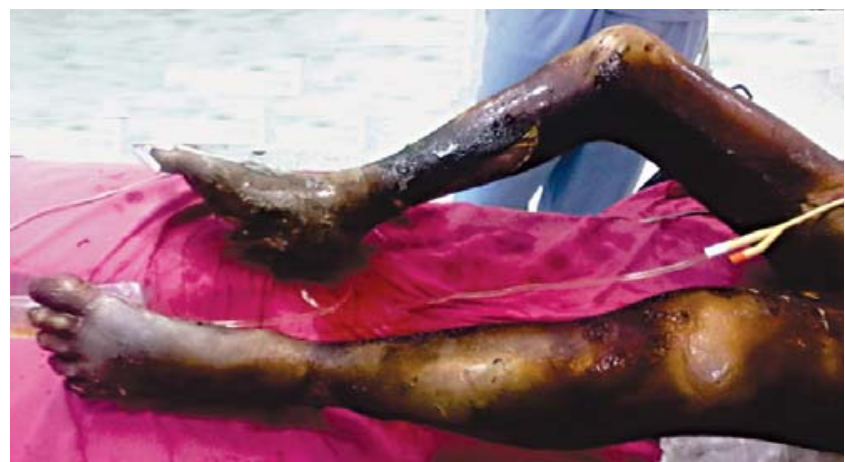

Figure 6. 
The topical treatment, the need of surgical intervention or debridement applied to the burn wound depen$\mathrm{ds}$ on the depth of the burn wound ${ }^{19}$.

Clinical assessment of burn depth has to be performed by an experienced burn surgeon, in order to determine which wounds are able to heal and which are deep and requires excision and grafting:

- Partial thickness burn (second degree burn) allows surviving of dermal elements, like sweat glands or hair follicles, which are able to heal the burn wound (Figure 7).

- Full-thickness burn (third degree burn) - destroy all dermal elements, without healing resources (Figures 8 and 9);

It is important for the length of hospitalization and cost of treatment of burn patients an early diagnosis of the deep burns and a well-timed surgical treatment of burn wounds ${ }^{16}$.

Burn depth may be determined by some non-invasive imaging techniques like terahertz imaging, near-infrared spectroscopic imaging, spatial-frequency-domain imaging and reflectance-mode confocal microscopy. Many of these techniques have not been sufficiently studied for clinical application ${ }^{20,21}$.

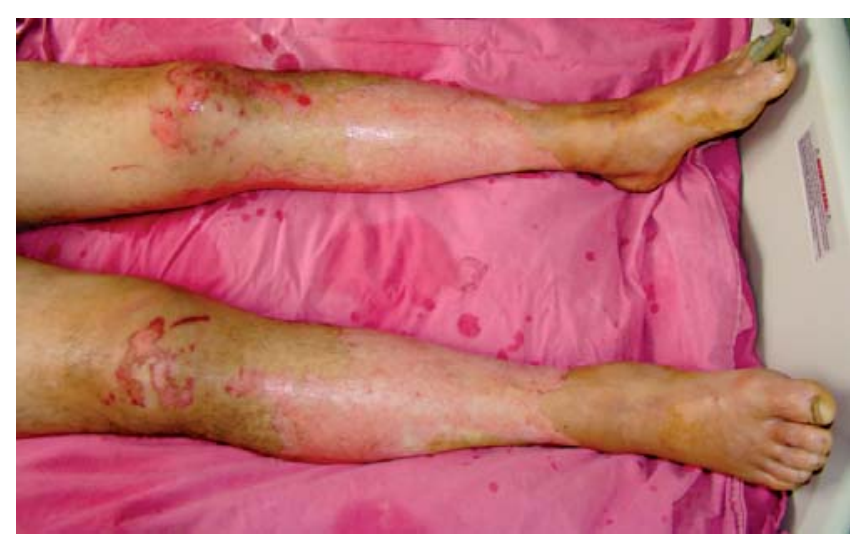

Figure 7.

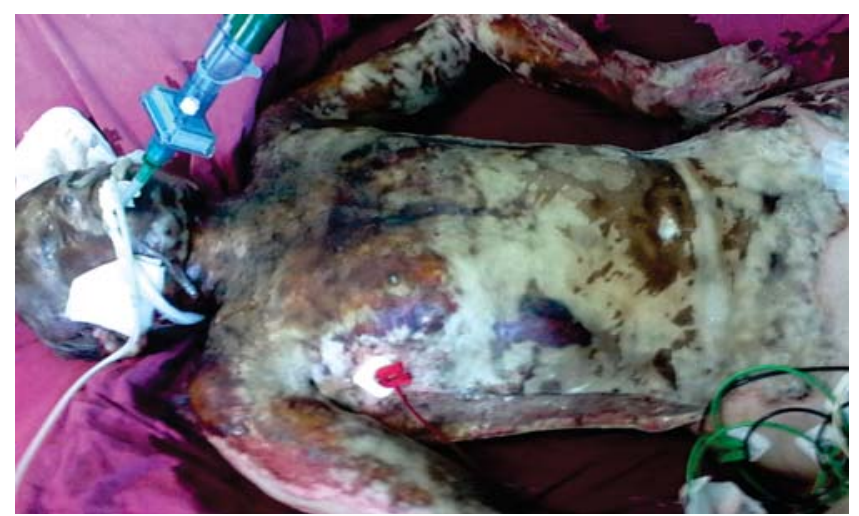

Figure 8.

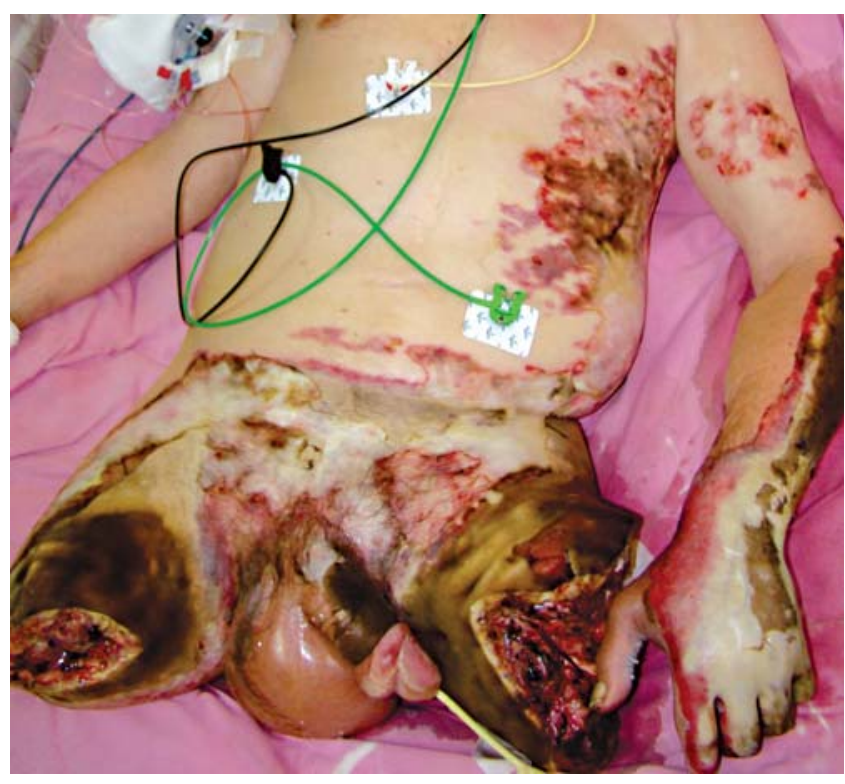

Figure 9. Extensive thermal injuries that required bilateral lower limb amputation on the day of admission and further ischemia in the left forearm and hand.

Laser Doppler imaging is a non-invasive, painless and easily performed method for burn depth evaluation, prevents unnecessary surgery, but is superior to visual-clinical assessment only $48 \mathrm{~h}$ after a burn injury ${ }^{22,23}$.

Reminding pathophysiology of the burn wound, the blood flow of the superficial burn is higher compared to normal tissue and less than the normal tissue in the deep burn wound. The microcirculation in the burn tissue worsens within 12-24 $\mathrm{h}$ after trauma and increases after 48 hours $^{23}$.

According to Jeng et al., if the perfusion velocity of the burn tissue was 150-250 PU, the burn was deep and these patients should undergo surgery and if perfusion velocity was $>250 \mathrm{PU}$ the burn was superficial and these patients should undergo conservative treatment ${ }^{24}$.

\section{Debridement of Burn Wounds}

Debridement means the removal of devitalized, necrotic tissues using surgical or chemical techniques. Our purpose is wound healing and after this maneuver wound surface is clean, with minimal microbial colonization and necrotic tissues, which allows it to cure more rapidly. Complete debridement of the wound should be done as quickly as possible. The debrided wound is not ready to support immediate permanent wound cover such a surgically excised wound ${ }^{16}$.

The Versajet hydrosurgery system (Smith \& Nephew, London, UK) is a device that functions based on the Venturi effect, able to cut and aspirate debris tissue. It is good for the treatment of partial thickness burns, 
as in the full thickness burns the sharp debridement is best required. Versajet hydrosurgery is used especially for debridement of the face, neck, lips, fingers, interdigital spaces, convex and concave areas. Thus, tissue excision is precise and it avoids the damage of viable tissue and its vascular supply $9,25,26$.

Another option is represented by the enzymatic debridement. Enzymatic debridement is considered to be a promising alternative to surgical excision and has been studied for half a century in order to investigate the potential of various non-surgical debridement agents and enzymatic debridement agents for burn wounds. In the last years, enzymatic debridement studies have promising results.

Application is possible outside the operation room, these is a minimal invasive procedure, with minor blood loss as long as sufficient analgesia is ensured during this otherwise very painful debridement procedure ${ }^{27}$.

NexoBrid (Figure 10) is a lyophilized, partially purified proteolytic protein mixture with increased specific enzymatic activity derived from bromelain. It is specific and selective in the removal of the necrotic tissue without harming surrounding skin. This is used only in Burn Units, in the first 48 hours from the trauma, a
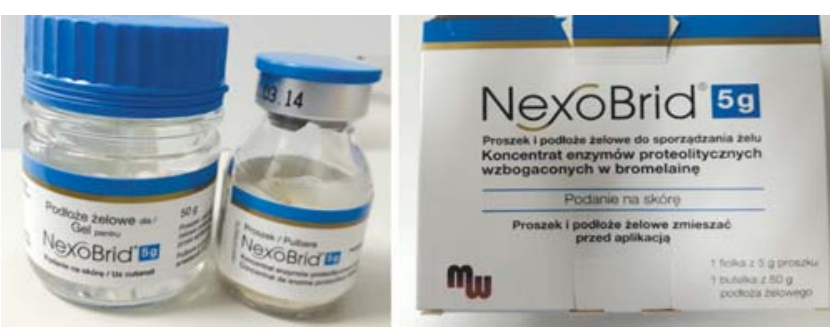

TBSA no more than $15 \%$, no more than one application is recommended, it is used in the first 15 minutes after preparation, it must be allowed to act for 4 hours and it is very expensive ${ }^{28}$.

In Figure 11, a patient is illustrated before and after we used NexoBrid on the burned hands.

\section{Excision of Burn Wounds}

Excision is a surgical procedure meaning incision through the deep dermis of open wounds or burn eschar and is typically performed on deep burns that would not heal spontaneously. The goal is to remove all necrotic and non-viable tissue to the level of viability without disturbing underlying structures. Unlike debridement, excision means a wound surface that is fully vascularized and ready for application of temporary or permanent skin substitute. Excision of a burn should be an elective procedure and done in a timely fashion, performed by experienced burn surgeons ${ }^{11}$.

Tangential excision means surgical removal of successive thin layers of the eschar down to viable tissue, using a dermatome (Figure 12). Healthy dermis appears white and shiny, therefore if the area is dull and gray or if clotted blood vessels are seen, the excision needs to be carried deeper, until proper bleeding of the wound. The tangential excision can be made with a Goulian knife, for delicate areas like face and hands or a Watson knife or dermatomes to excise larger areas like trunk and limbs ${ }^{15,19}$.

Fascial excision is reserved for patients with very deep burns (Figure 13). It is better to perform fascial excision using electrocautery in order to reduce intraoperative blood loss.

Figure 10.

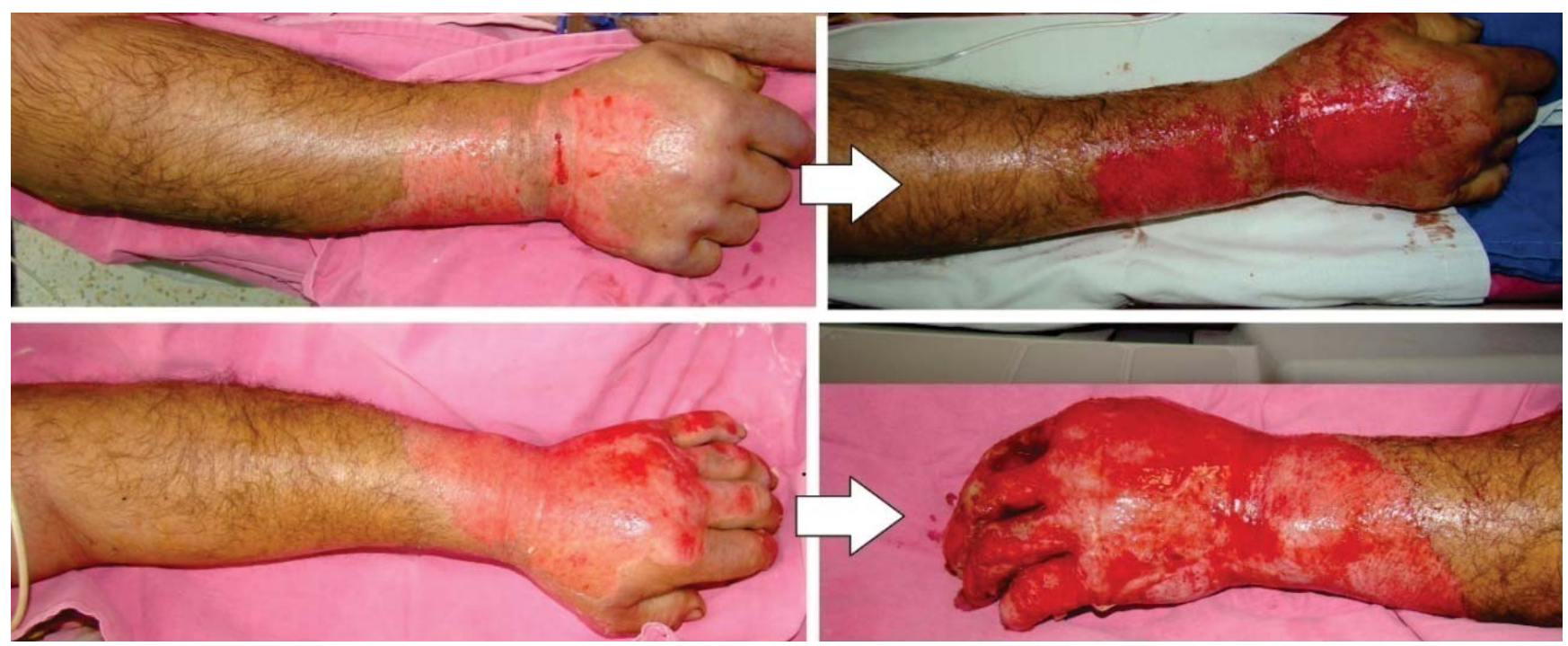

Figure 11. 


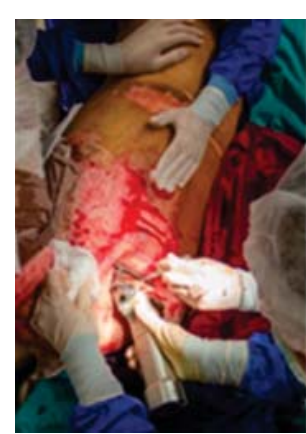

Figure 12.

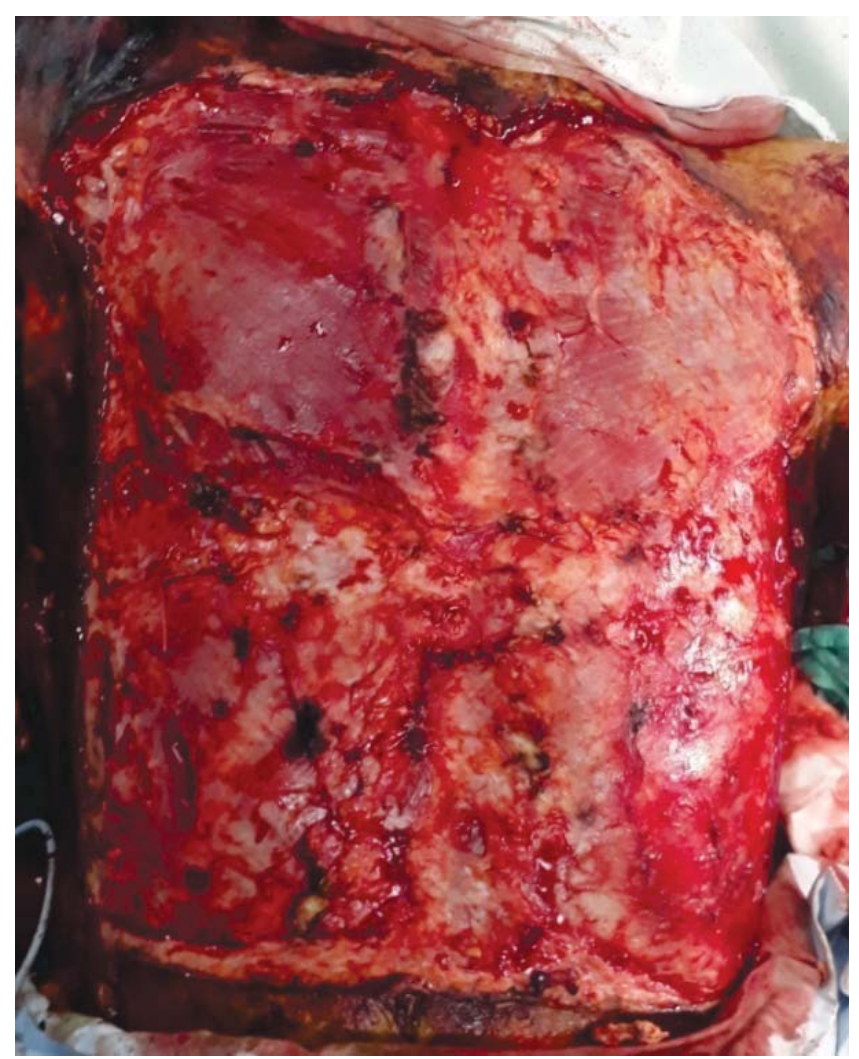

Figure 13.

The advantages of fascial excision are:

- Ensures a reliable bed for grafting.

- Tourniquets can be used for extremities.

- Less blood loss.

- Less experience is required.

The disadvantages of fascial excision include:

- Longer operative time.

- Unpleasant esthetic outcome, especially in obese patients.

- If the excision is circumferential, there is a great risk of distal edema.

- Risk of damaging the superficial tendons and nerves.
- Cutaneous denervation.

- If there is a relatively avascular fascia over joints, skin graft loss may appear and it may require eventual flap coverage ${ }^{9,19}$.

Surgery of the burn patients is a multiple-stage excision and grafting, in a planned sequence, first in functionally and cosmetically areas. The advantages of a multiple-stage procedure are that the results of the first excision can be viewed, with further excision if needed, meanwhile using on the wound temporary dressings, skin substitutes or skin replacements and also donor sites are given time to epithelize ${ }^{16}$.

\section{The coverage of excised burn wounds}

\section{Skin autologous grafts}

Split-thickness skin grafts from an uninjured donor site of the same patient are the gold standard for permanent burn wound closure. In order to achieve a good integration of the skin graft on the burn wound, it is important to have adequate wound bed preparation, suitable donor sites and a good postoperative care.

Skin grafts can be classified in full-thickness and split-thickness grafts, depending on how much dermis it contains; the advantage of a thin skin graft is a good integration ratio in the wound bed and a rapid heal of the defect on the donor site, but the disadvantage is a great degree of contraction.

Full-thickness skin grafts can be harvested from the flank, the groin crease, the inner of the arm, the supraclavicular area and the retroauricular area and can be used for coverage of small defects of the hand or the face.

Split-thickness grafts can be harvested from the anterolateral thigh (favorite donor site), the scalp, the posterior thorax, the buttocks and the abdomen. These donor sites can be reused for three times, but only after healing. The scalp can be used as a donor site for six times.

The split-thickness autografts can be used in different manner ${ }^{5,9,13,29}$ :

- Sheet graft: a piece of skin from an uninjured area, with a size of closure about the same as the graft taken (Figure 14). Because of the size, it is usually used for the face, neck and hands.

- Meshed skin graft: introduced by Tanner in 1964; variable expansion ratios used to increase the coverage area; the larger the ratio, the more area to cover $1: 1.5,1: 3,1: 4,1: 5$ or 1:6. Besides the expansion, another advantage is the drainage of body fluids and blood from wound bed. 


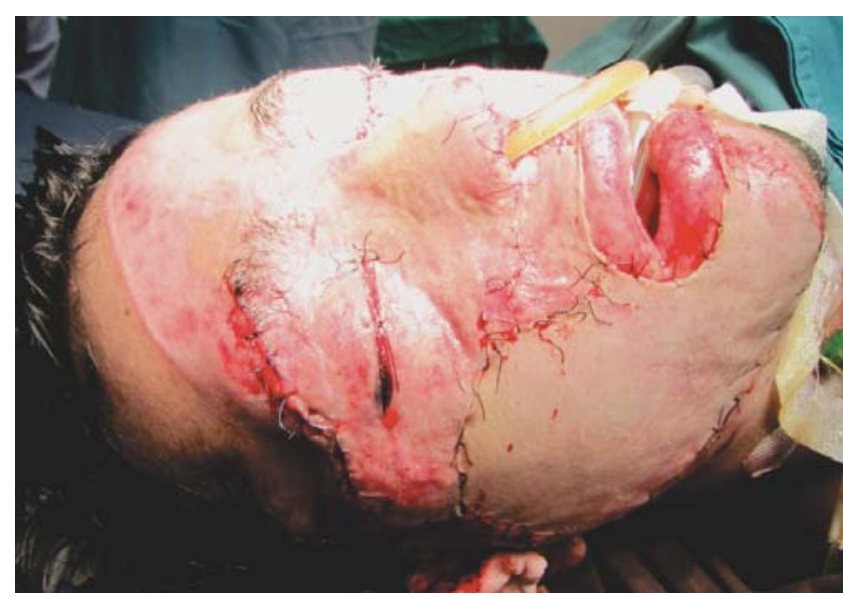

Figure 14.

Figures 15 and 16 present meshed 1:3 split-thickness autologous skin grafts on, in different evolution moments in two of our patients.

- "Meek" skin graft: technique introduced in 1958 by C.P Meek, with an expantion ratio of 1:9, using double pleated gauzes 9 .

Although autologous skin grafting remains the ideal solution for skin coverage, there are situations when autograftig is not possible: the defect to be covered is very large, like in extensive burns, the donor sites do not allow immediate and sufficient harvesting or the patient's general status is not allowing the grafting.

In these cases temporary or final coverage with skin substitutes may constitute a solution, able to save the patient's life.

\section{Skin Substitutes}

An integrative classification of skin substitutes is based on three main criteria: the lastingness of the product, the skin layers included in its composition and the origin of the compound (Figure 17) $)^{30,31}$.

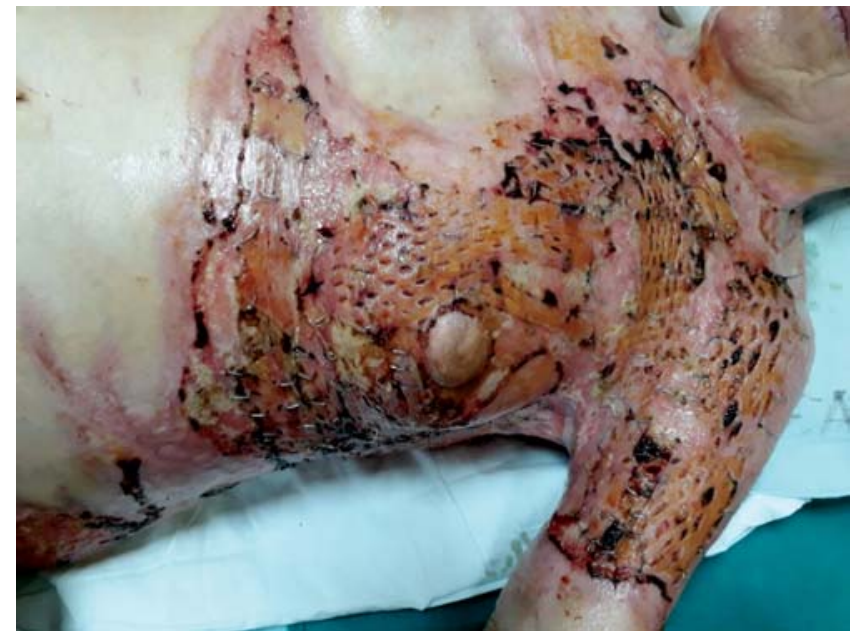

Figure 15.
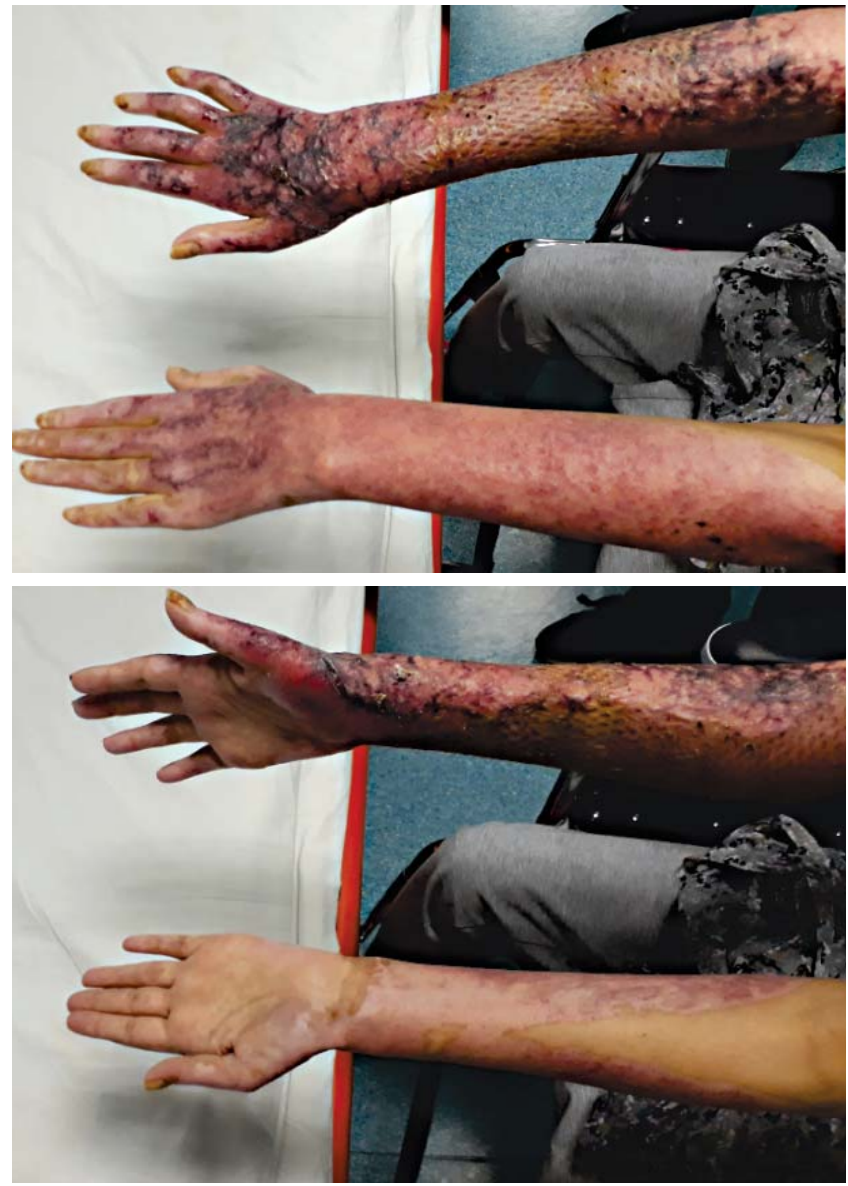

Figure 16.

\section{Temporary skin substitutes}

Temporary skin coverage solutions include:

- Biologic solutions:

- Allografts (homografts) - harvested from the cadaveric donors and banked or from living donors; used fresh, cryopreserved or preserved in glycerol. The allografts are frequently used for temporary coverage of excised burn wounds in case of extensive burns. The fresh and the cryopreserved allografts are living tissues that will be integrated and will be vascularized; within the next 2-4 weeks, raging on the host's immunological status, they undergo rejection, as non-self tissue; this requires removal (preferably before rejection) and coverage with autografts or permanent skin substitutes. Glycerol preserved allografts are used as a biological dressing, both in excised burns and in partially excised burns, in order to reduce fluid and protein losses. Disadvantages of using allografts are: rejection - can only be used as temporary substitutes, can be difficult to obtain, requi- 


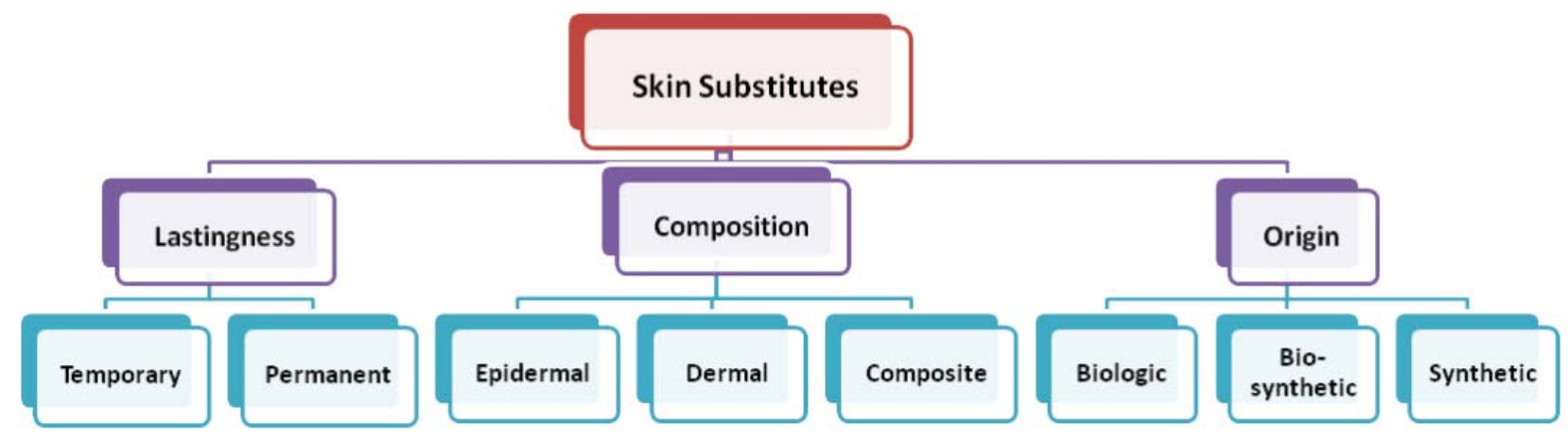

Figure 17.

re costs for harvesting, testing, storage, risk of bacterial and viral contamination ${ }^{5,13}$.

Below we present the allograft use in some of our patients (Figures 18-20).

- Amniotic membranes are another temporary skin coverage method, used and considered as biological dressings. Applying amniotic membranes should be preceded by tests to determine possible HIV or viral hepatitis contamination. They act effectively to stop the protein and electrolyte losses, but also against microbial invasion, remaining in place for 3-7 days (the need for frequent replacement and rapid distruction are their disadvantages) $)^{5,13,32}$.

- Heterografts or xenografts- skin from another species: porcine skin is a temporary, useful cover material, easy to obtain and relatively affordable. Xenografts adhere to the wound, do not vascularize, undergo a rejection process, and have a risk of contamination, are useful only as a biological dressing ${ }^{5,13}$.
- Synthetic substitutes:

The limitations of conventional bandages used for burn patients, recent improvements in technology and a better understanding of wound healing process determined an enormous expansion in the panel of dressing options suitable for burns ${ }^{33}$.

Several factors are taken into account for selection of a particular type of product for burn dressing: total body surface area, depth of the burn, general condition of the patient, wound bad status, wound location, frequency for dressing changes, the balance drainagemoisture retention, availability and costs ${ }^{8,34}$.

Burn wounds lose high amounts of fluids, so dressings must absorb fluid, while maintain an adequate insitu humidity (trough gas exchange and moisture retention) to promote granulation and epithelialization. Also, the burn dressing should provide anti-microbial barrier, to prevent infection. An important requirement is represented by the mechanical properties of the dressing in order to accomodate movement and enhance patient functional recover $y^{8,33,34}$.
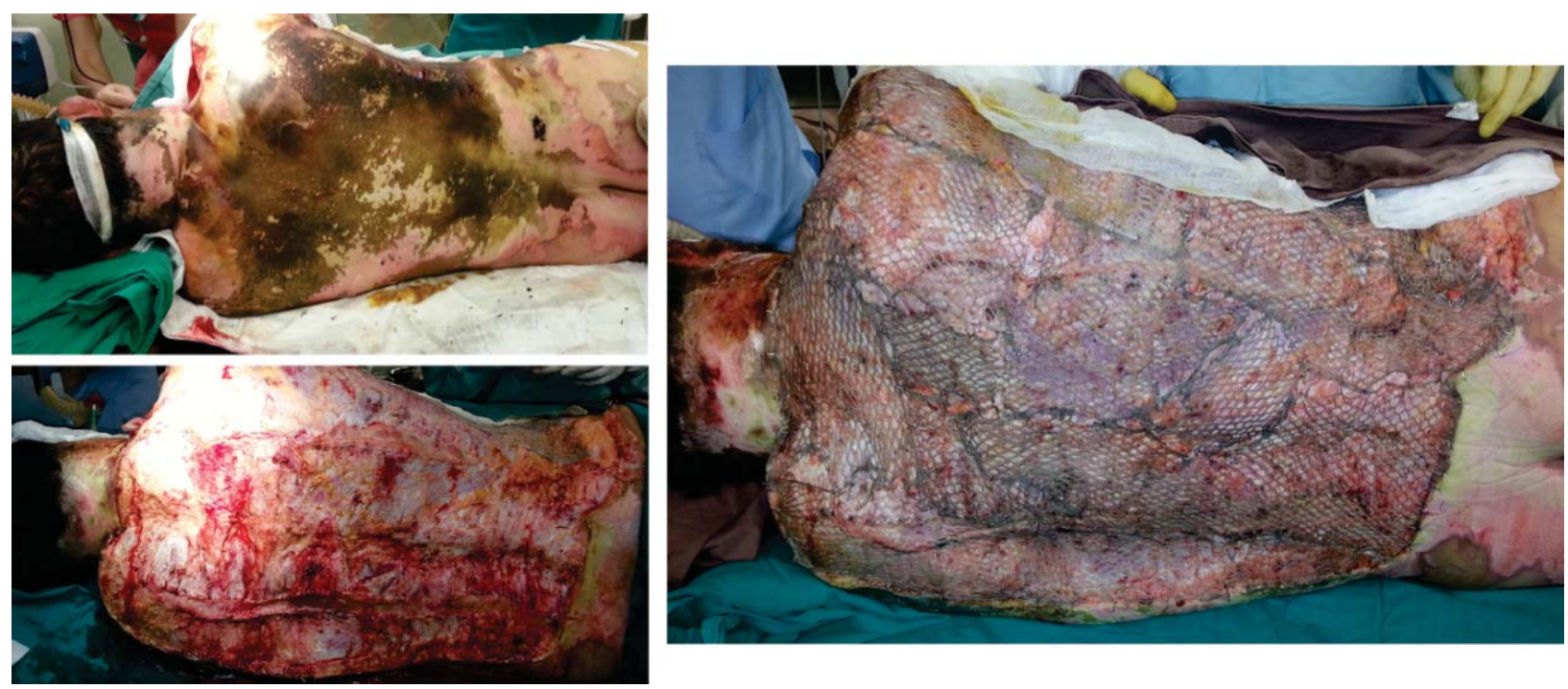

Figure 18. After fascial excision of the burn eschar of posterior thorax, the resulting defect is covered with meshed 1:3 split-thickness skin cadaveric allografts. 


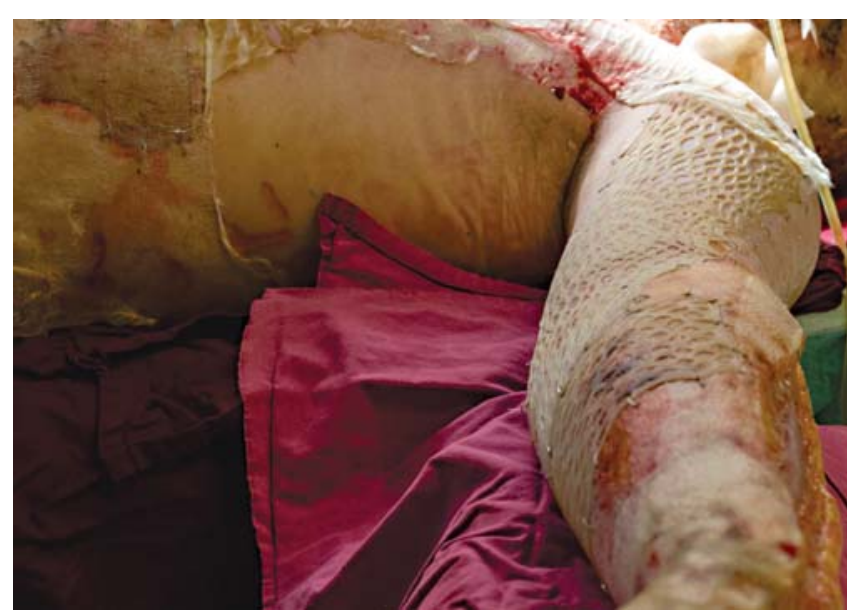

Figure 19. Split-thickness skin cadaveric allografts used for coverage of tangential-excised burns.

Major classes of dressings used for temporary coverage of the wounds in burn patients are presented in Table 2 with some examples of representative available commercial products:

In Figures 21 and 22 are presented two types of commercial dressings used in our patients.

- Biosynthetic products:

A more complex alternative to burned wound dressings is the development of synthetic and biosynthetic

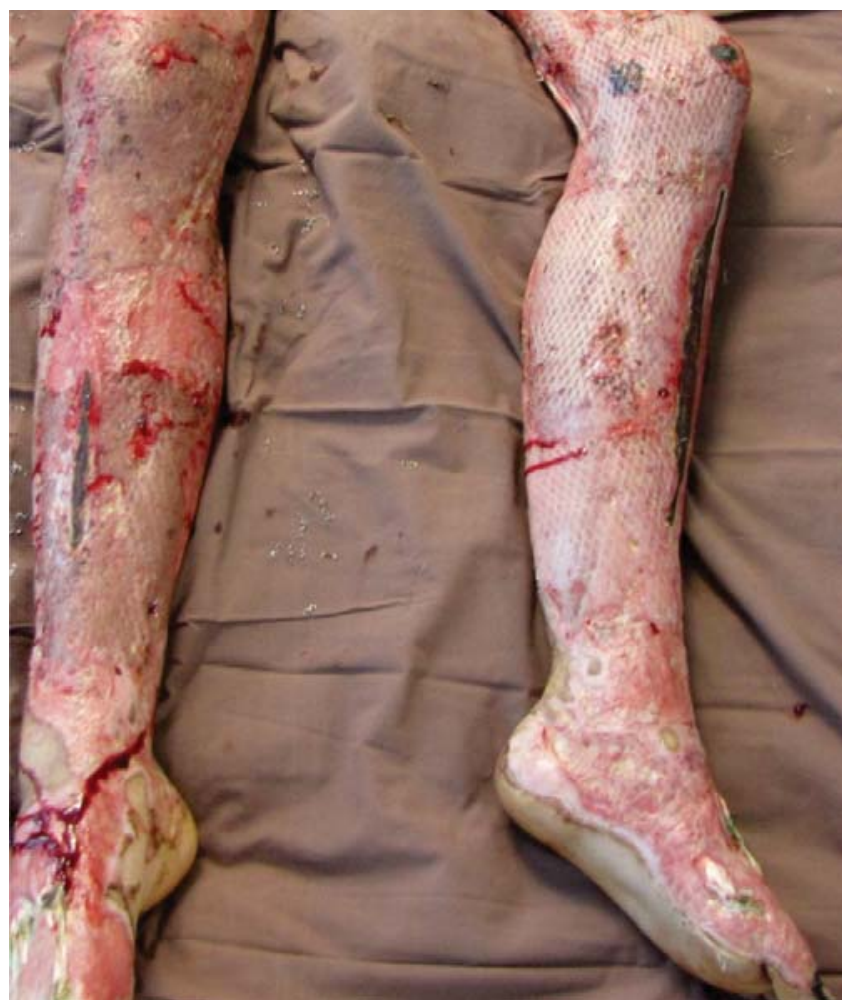

Figure 20. Split-thickness skin allografts harvested from living donors (patient's parents) used for coverage of fascial-excised burns; we can notice vascular integration of the skin allografts after 14 days, due to low immunological status of the patient and genetic related donors.

\section{Table 2. Burn Dressings Classification ${ }^{8,33}$}

\begin{tabular}{|c|c|}
\hline Major classes of dressings for burns & Products (Company) \\
\hline Alginate fibre dressings & $\begin{array}{l}\text { Aquacel (ConvaTec) } \\
\text { Sorbsan (Mylan) } \\
\text { Comfeel (Coloplast) } \\
\text { Algosteril (Johnson\&Johnson) } \\
\text { CarrasorbH (Carrington Laboratories), } \\
\text { Kaltostat (ConvaTec) } \\
\end{array}$ \\
\hline Antimicrobial & $\begin{array}{l}\text { Acticoat (Smith \& Nephew) } \\
\text { lodosorb (Smith \& Nephew) } \\
\text { Silverlon (Argentum) } \\
\text { Contreet - hydrocolloid with silver (Coloplast Corp) } \\
\text { Avance - foam with silver (Mölnlycke) } \\
\text { Aquacel Ag-fibre dressing with silver (ConvaTec). }\end{array}$ \\
\hline Collagen & $\begin{array}{l}\text { Puracol (Medline) } \\
\text { Fibracol (Johnson \& Johnson) } \\
\end{array}$ \\
\hline Hydrocolloid & \begin{tabular}{|l} 
DuoDerm (ConvaTec), \\
Granuflex (ConvaTec) \\
\end{tabular} \\
\hline Hydrogel & $\begin{array}{l}\text { Dermagel (Maximilian Zenho \&Co), } \\
\text { SilvaSorb (Medline), } \\
\text { Skintegrity (Medline) } \\
\text { IntraSite (Smith\&Nephew) } \\
\text { Solugel (Acelity), } \\
\text { Nu-gel (Johnson \& Johnson). }\end{array}$ \\
\hline Polyurethane film and foam dressings & $\begin{array}{l}\text { OpSite (Smith \& Nephew) } \\
\text { Tegaderm (3M Company) } \\
\text { Allevyn (Smith \&Nephew) } \\
\text { Lyofoa (Molnycke) } \\
\end{array}$ \\
\hline Silicon-coated nylon dressings & Mepitel (Mölnlycke) \\
\hline
\end{tabular}




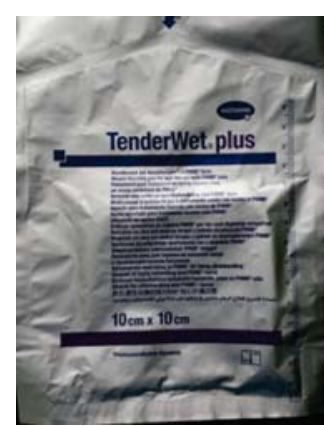

Figure 21.

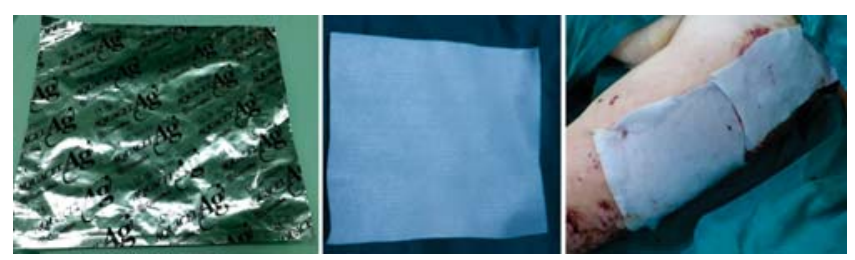

Figure 22.

temporary skin substitutes. We further present some products that has shown good results in clinical practice for burn wound coverage:

- Biobrane represents a synthetic semi-permeable membrane covered with porcine collagen. It ensures an adequate coverage barrier for water evaporation and microbial invasion, reducing also pain during burn wound healing ${ }^{35}$.

- TransCyte (Dermagraft-TC) is the first temporary skin substitute obtained by bioengineering, which has been approved by the FDA for the coverage of excised full-thickness burn wounds ${ }^{36}$.

- Veloderm (Cristalcelli77 ${ }^{\mathrm{TM}}$, BTC, Italy) is an occlusive temporary skin substitute, produced from bacterial cellulose, having the aspect of a thin, translucent membrane with good absorbtion properties (can retain liquid up to five times its own weight). For application on burned area is hydrated with saline solution, becoming soft, flexible and adherent to the wound bed, persisting until the wound healing. Its transparency constitutes an advantage in observing in dynamics the aspect of wound bed ${ }^{37}$. Veloderm (Figure 23) is a safe and efficient to be applied also on donor sites of skin grafts in burn or reconstructive surgery patients ${ }^{38-39}$.

\section{Permanent skin substitutes}

The research of the last decades has been focused on creating structures that can be used in place of autografts for definitive skin coverage Permanent skin substitutes addresses to epidermal or replacement or both skin layers in case of composite products. Epi-
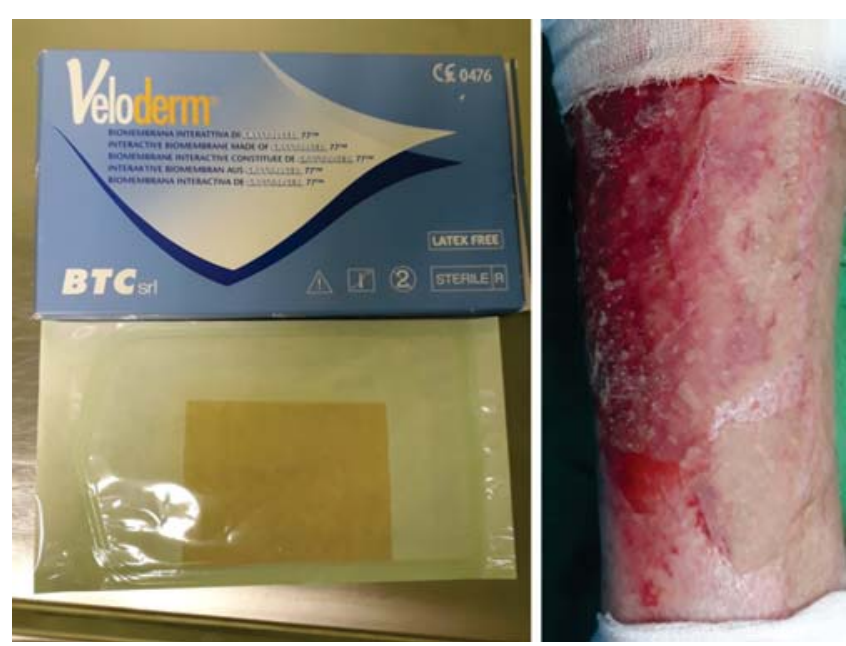

Figure 23. Veloderm use on a debrided forearm burn.

dermal replacement is usual obtain trough cell culture and applied as epidermal sheets or in form of suspension which is sprayed. Dermal replacement is achieved trough autografts, allografts, decellularized dermis or biosynthetic scaffolds ${ }^{40}$.

To be effective and acceptable, the skin substitutes must have the following characteristics ${ }^{41}$ :

1. Biocompatibility

2. Antimicrobial resistance

3. Thermal and microbial barrier function

4. Shear strength

5. Lack of antigenicity

6. Thickness appropriate but keeping elasticity and flexibility

7. Stability in time, normal skin growth-like ability

8. Adaptable shape for irregular surfaces

9. Easy to apply and adhere to the recipient area

10. Availability, accessibility in procuring it

11. Keeping properties in time and ease of storage

12. Efficiency in terms of costs

- Epidermal substitutes

The discovery of epidermal substitutes is based on the research conducted by James Rheinwald and Howard Green in 1975, being the first ones carried out the isolation of epidermal keratinocytes and their in vitro cultivation on irradiated murine fibroblasts ${ }^{42}$.

In 1981, O'Connor introduced to the clinic the grafting of major burns with autologous keratinocyte cultures $^{43}$. The first commercial product for clinical use was made in 1988, under the name EPICEL ${ }^{44}$. The time for obtaining a sufficient area of cultured epidermal cells is 2-3 weeks from the harvest, during which the patient must be covered with temporary substitutes.

The use of keratinocyte cultures is still a common practice in multiple burn centers ${ }^{45}$. 
Advantages of epidermal substitutes are: large surfaces can be obtained in a relatively short time (on average 16 days), from small samples (a few $\mathrm{cm}^{2}$ ), they act as permanent coverage; they are not rejected, being autologous compounds 5 .

Also there are disadvantages of epidermal substites: the epidermal structure is fragile, difficult to manipulate, mechanical instability, being in lack of dermal support, frequent eczematizations appear, can give important retractions, lack of good cosmetic and functional results (epidermal instability requires long immobilization time, high costs. As a solution to these problems, Pellegrini proposed ex-vivo expansion of keratinocytes and cultivation on a fibrin substrate resulting in a higher stem cell populations and demonstrating superior results in grafting and stability in time ${ }^{46}$.

- Dermal and bilaminar substitutes

Dermal substitutes are very important for the coverage of full-skin defects, both on acute and chronic wound ${ }^{47}$. Several dermal or dermo-epidermal substitutes are already on market, used with very good results.

- Integra (Integra LifeSciences Corp., Plainsboro, NJ, USA) is the most currently used dermal substitute. Integra is a product consisting of chondroitin 6-sulfate, bovine collagen and a silastic membrane developed on the principles of Yannas and Burke ${ }^{48,49}$. The dermal layer (internal)
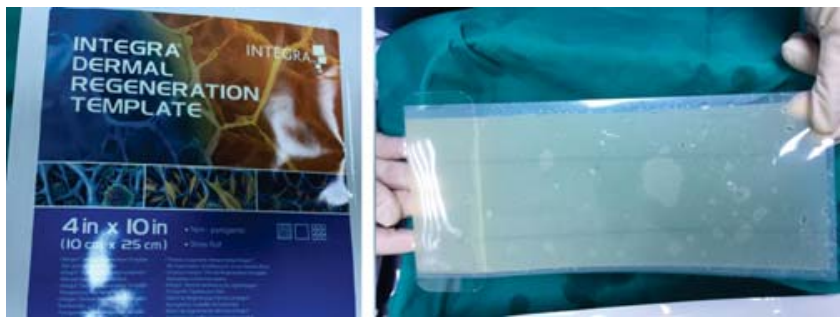

Figure 24 .

contains a combination of bovine collagen fibers, glycosaminoglycans and chondroitin 6-sulfate, having a thickness of $\sim 2 \mathrm{~mm}$. This layer has pores of approximately $70-200 \mu \mathrm{m}$, that allow the growth of fibroblasts. The epidermal layer (external) consists of a polysiloxane polymer, is a temporary layer with a thickness of $0.23 \mathrm{~mm}$, which is replaced after about 2-3 weeks with the split skin graft. It represents a barrier for infectious agents, controls liquid losses and it is a mechanical support. Integra (Figures 24-26) is applied to clean, excised wounds, no significant immunological problems of any kind have been reported so far. Integra has large utility, being frequently quoted as an important means in the acute surgical treatment of large burns, as well as in the post-burn reconstruction. Disadvanta-
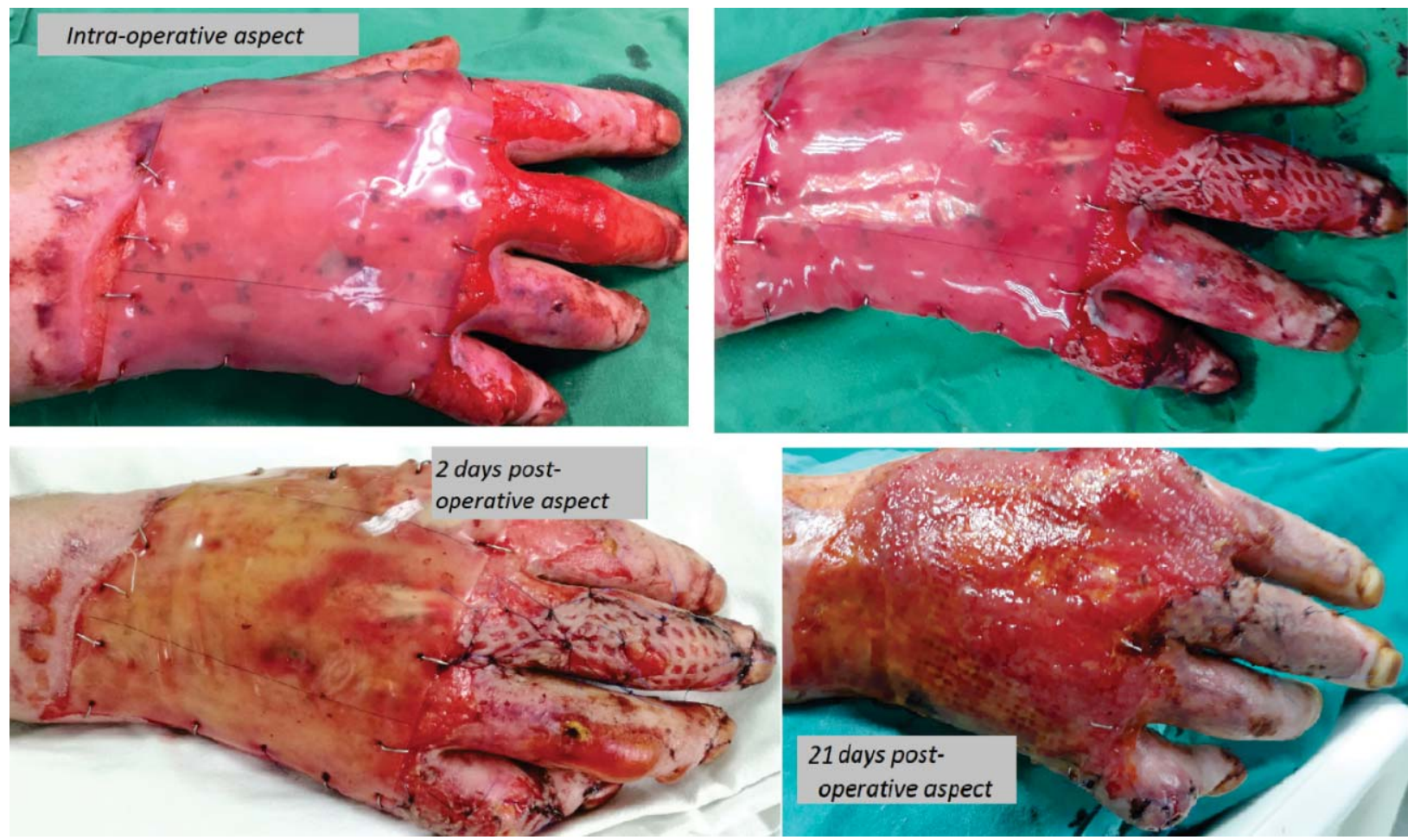

Figure 25. Integra used on the dorsum of the hand where there was an exposure of extensor tendons in II-III digital rays and the AMF II articulation, with the dermis appearance after 21 days, before the split thickness skin grafting and the coverage of the elements. 

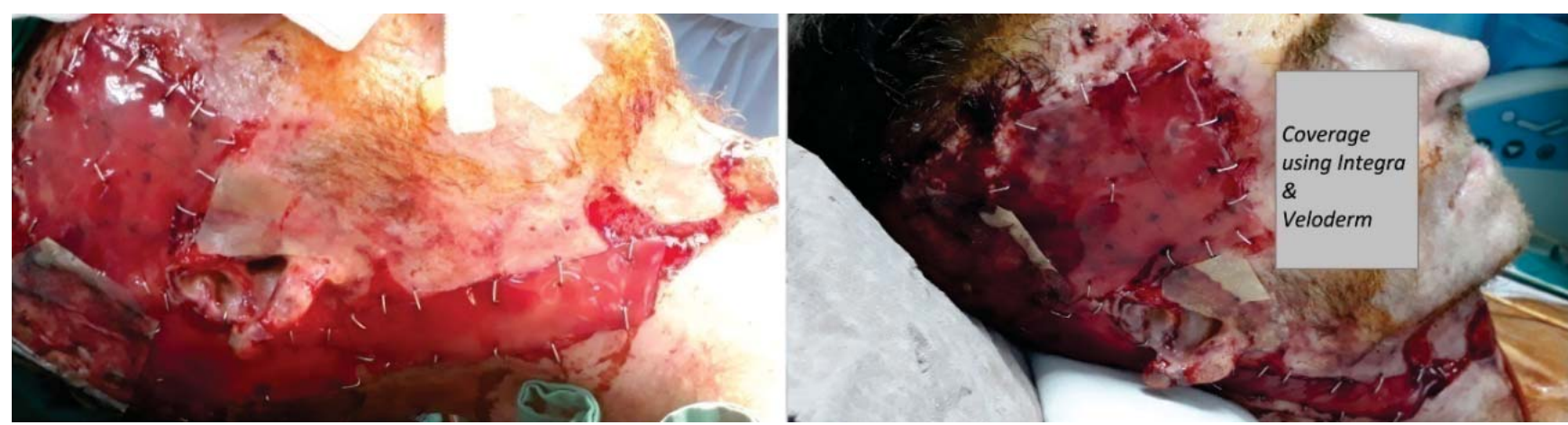

Figure 26. Integra used on the head and neck carefully debrided lesions.

ges include: high cost, difficulty in applying on large and irregular surfaces and on maintaining adherence to the wound; requirement of further autografting $5,13,49$.

- AlloDerm (LifeCell, Branchburg, New Jersey) is an acellular dermal substitute obtained from cryopreserved, dezepidermized cadaveric skin. It gives dermal support, over which is applied a very thin autologous skin graft; grafting can be done in the same operatory time, which is an advantage compared to Integra. Good results on scars and good integration have been achieved $^{13}$.

- Apligraf (Organogenesis, Canton, MA) is a bilaminated skin substitute approved by the Food and Drug Administration (FDA) to be used in the case of trophic ulcers that have not been $\mathrm{cu}^{-}$ red by other methods ${ }^{50,51}$. For burn lesions, there are few studies reported-Apligraf in combination with autograft produced good results in terms of wound closure rates ${ }^{52}$.

We have to keep in mind that for successful take of a skin substitute a good vascularization is mandatory, depending of vasculogenesis ability of the scaffold and presence of sprouting capillaries originating in wound bed $^{53}$.

In patients presenting severe deep or extensive burns, the main aspect in burn wound care is the microbial efficacy of the applied products ${ }^{8}$.

\section{The Use of Flaps in Acute Burn Management}

Skin grafting remains the main therapeutic surgical strategy in acute burns treatment. Utilization of local advancement, transposition or rotation flaps is rarely required in acute phase of burns, those surgical procedures address more to the chronic burns sequel.

Regional pedicle flaps or free microsurgical transferred flaps may be necessary in severe deep lesions, like high voltage electrocutions when deep structures (tendons, bones, vesselsand nerves) are exposed or in facial lesions; in those situations we need well vascularized adequate coverage. Those results can be obtained using robust pedicle or free muscle or musculocutaneous flaps (like latissimus dorsi, anterolateral thigh flap or rectus abdominis flaps). When performing a free flap in a burned area, we have to take into consideration some technical aspects regarding recipient bed status and available recipient blood vessels (the microvascular anastomoses should be placed at a safe distance from the lesion, in healthy tissue to avoid thrombotic complications and flap loss). Using the vessel grafts may be necessary when performing the anastomoses. A carefully postoperative monitorization of the flap is required.

\section{Vascularized Composite Allotransplantation (VCA)}

Vascularized composite allotransplantation represents an emerging surgical strategy with great potential for burned patient with severe deformity, imposible to approach trough conventional reconstructive techniques. Upper limb or face allotransplantation shown good clinical results in recent worldwide experience. Drawbacks to an extensive use of this therapeutic strategy are the necessity for lifelong immunosuppressive therapy which is associated with multiple complications. We analyzed this possibility for our patients and concluded that the severe burned patient has a particular systemic clinical and immunologic status that impose precaution in select VCA as therapeutic option, until better results will be obtain in immunologic field for promoting transplant tolerance ${ }^{54}$.

\section{The Importance of the Rehabilitation Program}

In burn patients we cannot dissociate surgical treatment from the adequate rehabilitation program. It is mandatory for patients to start the recovery even from the acute phase of the burn and adhere to a complex 
rehabilitation programs that extends trough years after hospital discharge. Physiotherapy represents an integral component in complex burn care with the purpose to keep muscular trophicity, regain the range of motions, prevent contractures, improve function and promote psycho-social wellbeing and integration ability ${ }^{9}$.

\section{Future direction}

Further research in extensive burns field is orientated to develop sustainable strategies that ensures a higher survival of burn patients, with good functional and aesthetic results with the final goal of social and professional reinsertion of those patients.

Tissue engineering addresses, trough extensive research, to develop better skin substitutes able to restore the lost biologic functions, having in mind ethical, safety, efficiency and economic considerations. Tissue engineering combines elements of biomaterials and cell transplantation in order to substitute lost tissues and promote structural and functional optimal regeneration $^{55,56}$. Various stem cells population cultured on different extracellular matrices are analyzed for their promising results for skin regeneration.

\section{CONCLUSIONS}

Main challenges in the treatment of acute severe burns include appropriate initial resuscitation, support vital functions and preventing severe complications, especially infections. For this reason, it is critical to apply a prompt surgical strategy with early excision of burn eschar and coverage of the wound.

Using of autologous skin grafts still remain the best surgical options in acute phase of the severe burns. Unfortunately, often autografts are not available and skin substitutes remain the solution for our patients. Currently, there is no ideal skin substitute on the market that would effectively cure tissue defects without scars. There is a continuous research to improve the structural properties of the existing substitutes, to perform comparative studies between different products, to evaluate new synthetic and biological materials for use in tissue regeneration and cost optimization to allow widespread use of these therapeutic methods.

Early adherence of the patient to a well established rehabilitation program is another key point in severe burn injuries management.

The ultimate desiderate for those patients is regain their social and professional attribution as close as possible to normality, therefore a sustained follow-up and support program is mandatory.

12. Vinita P, Khare NA, Chandramouli MV, Shende N, Bharadwaj S. Comparative analysis of early excision and grafting vs delayed grafting in burn patients in a developing country. J Burn Care Res. 2016;37(5):278-82.

13. Sterling JP, Heimbach DM, Gibran NS. Management of the burn wound. In: ACS surgery: principles and practice. Hamilton, ON: Decker; 2010. http://dx.doi.org/10.2310/7800.S07C15.

14. Hettiaratchy S, Dziewulski P. Pathophysiology and types of burns. BMJ: British Medical Journal. 2004;328(7453):14271429

15. Kamolz LP, Kitzinger HB, Andel,H, Frey M. The surgical treatment of acute burns. Eur Surg. 2006; 38(6): 417-423

16. Kagan RJ, Peck MD, Ahrenholz DH, Hickerson WL, Holmes J 4th, Korentager R, Kraatz J, Pollock K, Kotoski G. Surgical management of the burn wound and use of skin substitutes: an expert panel white paper. J Burn Care Res. 2013 Mar-Apr;34(2):e60-79.

17. Murphy AD, Healy C, Purcell E, Fitzgerald E, Kelly JL. An assessment of burn care professionals' attitudes to major burn. Burns. 2008;34:512-18.

18. Serghiou MA, Niszczak J, Parry I, Richard R, Clinical practice recommendations for positioning of the burn patient; Burns, 2016;42(2):267-75

19. Barret-Nerín JP, Herndon DN, Principles and practice of burn surgery, Taylor \& Francis, 2005

20. Cross KM, Leonardi L, Gomez M, Freisen JR, Levasseur MA, Schattka BJ, et al. Noninvasive measurement of edema in partial thickness burn wounds. J Burn Care Res. 2009;30:807-17.

21. Sowa MG, Leonardi L, Payette JR, Fish JS, Mantsch HH. Near infrared spectroscopic assessment of hemodynamic changes in the early post-burn period. Burns. 2001;27:241-9. 
22. Hoeksema $H$, Van de Sijpe $K$, Tondu T, Hamdi M, Van Landuyt $\mathrm{K}$, Blondeel $\mathrm{P}$, et al. Accuracy of early burn depth assessment by laser Doppler imaging on different days post burn. Burns 2009;35:36-45

23. Venclauskiene A, Basevicius A, Zacharevskij E, Vaicekauskas V, Rimdeika R, Lukosevicius S. Laser Doppler imaging as a tool in the burn wound treatment protocol. Videosurgery and other Miniinvasive Techniques. 2014;9(1):24-30.

24. Jeng JC, Bridgeman A, Shivnan L, et al. Laser Doppler imaging determines need for excision and grafting in advance of clinical judgment: a prospective blinded trial. Burns. 2003;29:665-70.

25. Klein MB, Hunter S, Heimbach DM, Engrav LH, Honari S, Gallery $\mathrm{E}$, et al. The Versajet water dissector: a new tool for tangential excision. J Burn Care Rehabil. 2005;26:483-7.

26. Hyland EJ, D'Cruz R, Menon S, Chan Q, Hawey JG, Lawrence T, et al. Prospective, randomised controlled trial comparing VersajetTM hydrosurgery and conventional debridement of partial thickness paediatric burns. Burns. 2015;41:700-7.

27. Klasen HJ. A review on the nonoperative removal of necrotic tissue from burn wounds. Burns. 2000;26:207-22.

28. Rosenberg $L$, Krieger $Y$, Bogdanov-Berezovsky A, Silberstein $E$, Shoham Y, Singer AJ. A novel rapid and selective enzymatic debridement agent for burn wound management: a multi-center RCT. Burns. 2014;40:466-74.

29. Seyhan T. Split-Thickness Skin Grafts, chapter in Spear M(Ed.). Skin Grafts - Indications, Applications and Current Research. In Tech 2011, available from www.intechopen.com

30. Ferreira MC, Paggiaro AO, Isaac C, Teixeira Neto N, Santos GB dos. Skin substitutes: current concepts and a new classification system. Rev. Bras. Cir. Plást. 2011; 26(4): 696-702.

31. Damanhuri MH, Boyle JM, Enoch S. Advances in tissue-engineered skin substitutes, Wounds International.2011; 2 (1):27-34.

32. Eskandarlou M, Azimi M, Rabiee S, Seif Rabiee MA. The Healing Effect of Amniotic Membrane in Burn Patients. World Journal of Plastic Surgery. 2016;5(1):39-44

33. Wasiak J, Cleland H, Campbell F, Spinks A. Dressings for superficial and partial thickness burns. Cochrane Database Syst Rev. 2013 Mar 28;(3):CD002106. doi: 10.1002/14651858.CD002106. pub4.

34. Broussard KC, Powers JG. Wound dressings: selecting the most appropriate type. Am J Clin Dermatol. 2013;14:449-59.

35. Whitaker IS, Prowse S, Potokar TS. A critical evaluation of the use of Biobrane as a biologic skin substitute: a versatile tool for the plastic and reconstructive surgeon, Ann Plast Surg. 2008;60(3):333-7

36. Ruszczak Z. Effect of collagen matrices on dermal wound healing., Adv Drug Deliv Rev. 200328;55(12):1595-611.

37. Alves HR, de Almeida PC, Grillo VA, Smaniotto P, Santos DV, Ferreira MC. Clinical experiences of using a cellulose dressing on burns and donor site wounds. J Wound Care. 2009;18(1):27-30.

38. Liu J, Li Y, Rong X, Lin W, Zhang T, Wang B, Li XB, Jiang S, Zhang Q. Application of crystalline cellulose membrane (Veloderm) on split-thickness skin graft donor sites in burn or reconstructive plastic surgery patients. J Burn Care Res. 2013;34(3):e176-82.
39. Melandri D, De Angelis A, Orioli R, Ponzielli G, Lualdi P, Giarratana N, Reiner V. Use of a new hemicellulose dressing (Veloderm) for the treatment of split-thickness skin graft donor sites A within-patient controlled study. Burns. 2006;32(8):964-72.

40. Nyame TT, Chiang HA, Leavitt T, Ozambela M, Orgill DP. TissueEngineered Skin Substitutes. Plast Reconstr Surg. 2015;136(6): 1379-88.

41. Shores JT, Gabriel A, Gupta S. Skin substitutes and alternatives: a review. Adv Skin Wound Care 2007; 20: 493-508.

42. Rheinwald JG, Green H. Serial cultivation of strains of human epidermal keratinocytes: the formation of keratinizing colonies from single cells. Cell. 1975;6:331-43.

43. O'Connor NE, Mulliken JB, Banks-Schlegel S, et al. Grafting of burns with cultured epithelium prepared from autologous epidermal cells. Lancet. 1981;1(8211):75-8

44. http://www.epicel.com

45. Wood FM, Kolybaba ML, Allen P. The use of cultured epithelia autograft in the treatment of major burn wounds: Eleven years of clinical experience. Burns. 2006;32:538-44.

46. Pellegrini G, Ranno R, Stracuzzi G, Bondanza S, Guerra L, Zambruno G, Micali G, De Luca M. The control of epidermal stem cells (holoclones) in the treatment of massive full-thickness burns with autologous keratinocytes cultured on fibrin. Transplantation. 1999.27;68(6):868-79

47. Van der Veen VC, van der Wal MB, van Leeuwen MC, Ulrich MM, Middelkoop E. Biological background of dermal substitutes. Burns. 2010;36:305-21

48. Burke JF, Yannas IV, Quinby WC Jr, Bondoc CC, Jung WK, Successful use of a physiologically acceptable artificial skin in the treatment of extensive burn injury, Ann Surg. 1981; 194(4):41328

49. http://www.ilstraining.com

50. Zaulyanov L., Kirsner R., A review of a bi-layered living cell treatment (Apligraf ${ }^{\circledR}$ ) in the treatment of venous leg ulcers and diabetic foot ulcers, Clin Interv Aging. 2007 March; 2(1): 93-98.

51. Apligraf ${ }^{\circledR}$, available from http://www.woundsource.com/product/apligraf

52. Waymack P, Duff RG, Sabolinski M. The effect of a tissueengineered bilayered living skin analog, over meshed splitthickness autografts on the healing of excised burn wounds. The Apligraf Burn Study Group. Burns 2000;26(7):609-19.

53. Sheikholeslam M, Wright MEE, Jeschke MG, Amini-Nik S. Biomaterials for Skin Substitutes. Adv Healthc Mater. 2017 Dec 22. doi: 10.1002/adhm.201700897.

54. Grosu-Bularda A., Popescu SA, Teodoreanu R., Cojocaru L., Lazarescu L, Lascar I., Is Vascularized Composite Allotransplantation a Suitable Reconstructive Option for Extensive Defects in Burned Patients?Clinical and Immunological Evaluation Protocol, Modern Medicine, 2016, Vol. 23, Nr.2, 124-134.

55. dos Sanos V, Brandalise RN, Savaris M, Biomaterials: Characteristics and Properties, chapter in dos Sanos V, Brandalise RN Savaris M Engineering of Biomaterials, Springer 2017

56. Furth ME, Atala A, Future Perspectives, chapter in Lanza R, Langer R, Vacanti J, Principles of Tissue Engineering, Third Edition, Elsevier Inc, 2007. 